\title{
Understanding latent demand for hybrid and plug-in electric vehicles using large-scale longitudinal survey data of US new vehicle buyers
}

\author{
Rubal Dua • Kenneth White
}

Received: 12 February 2019 /Accepted: 13 April 2020 / Published online: 27 April 2020

(C) The Author(s) 2020

\begin{abstract}
Consumer adoption of fuel-efficient vehicles is a crucial step in improving energy efficiency of the light-duty vehicle sector. To promote adoption, policymakers have employed various demand- and supply-side policies including incentives, fuel economy standards, zero emission vehicle mandate, among others. This paper measures the changes in consumers' purchase motivations and latent demand for hybrid and plug-in electric vehicles in the wake of such programs by analyzing the past 11 years of new vehicle buyer survey data in the USA with more than 1 million respondents. The analysis reveals that electric vehicles - including hybrids, plug-in hybrids, and pure battery electric, collectively termed xEVs - had the potential to secure as much as $\sim 11 \%$ of the US market in 2015 , but the actual market share was only onethird of this. A narrowing of the consumer's valuation gap between buyers of non-xEVs and xEVs for purchase motivations - including fuel economy, environmental friendliness, technical innovation, and price-is responsible for the increase in the latent demand for $\mathrm{xEVs}$. The term valuation gap refers to the difference between the average rating given by non-xEV and
\end{abstract}

Electronic supplementary material The online version of this article (https://doi.org/10.1007/s12053-020-09865-5) contains supplementary material, which is available to authorized users.

R. Dua $(\bowtie) \cdot K$. White

King Abdullah Petroleum Studies and Research Center (KAPSARC), P.O. Box 88550, Riyadh 11672, Saudi Arabia e-mail: rubal.dua@kapsarc.org
xEV buyers for a particular purchase motivation question in the survey. The closer the ratings, the smaller will be the valuation gap. Policy instruments such as sales-weighted fuel economy target show strong correlation with the consumer valuation gap. In combination with demand-side policies that make xEVs more accessible to mainstream consumers, they could be considered as viable tools if policymakers are seeking to nudge consumers toward xEVs.

Keywords Plug-in electric vehicle · Fuel economy targets · Consumer adoption · Large-scale new vehicle buyer survey data

\section{Introduction}

Federal- and state-level policy programs in the USA encourage automakers to sell fuel-efficient and alternative-fuel vehicles. Emissions reduction, air quality improvement, and energy security drive such programs to achieve these intended goals.

The federal-level Greenhouse Gas (GHG) and Corporate Average Fuel Economy (CAFE) programs require automakers to achieve a specific sales-weighted average of GHG emissions per mile/fuel economy each year up to model year (MY) 2025 (National highway traffic safety administration 2019; United States Environmental Protection Agency 2018). The statelevel Zero emission vehicle (ZEV) mandate in California and nine other US states promotes the adoption of ZEVs by requiring automakers to achieve a set target of 
ZEV sales each year (Union of Concerned Scientists 2016). Both programs are examples of supply-side policies with specific targets that increase annually. To promote ZEV adoption, states have also implemented demand-side policies such as offering rebates up to about $\$ 2500$, as well as incentives such as highoccupancy vehicle (HOV) lane permits (Center for Climate and Energy Solutions 2019). In the past, similar support incentives were also offered to promote hybrid electric vehicle (HEV) adoption (Gallagher and Muehlegger 2011). US states are also investing in and providing incentives to consumers for installation of charging infrastructure (Peterson and Michalek 2013).

The success of such policy programs depends on consumer adoption. Until now, most research aimed at understanding consumer inclination to adopt fuel-efficient and alternative-fuel vehicles relied on stated preference surveys (Al-Alawi and Bradley 2013; Rezvani et al. 2015; Carley et al. 2013; Egbue and Long 2012; Krupa et al. 2014; Lieven et al. 2011; Ščasný et al. 2018; Bunch et al. 1993; Chorus et al. 2013; Ewing and Sarigöllü 2000; Hackbarth and Madlener 2013; Hoen and Koetse 2014; Molin and van Wee 2017; Liao et al. 2019). However, in stated preference experiments, consumers may not fully express their preferences given the choice set, how that choice set is framed, and whether the incentives are fully reflected in the choices presented. They tend to react differently to hypothetical choice experiments than they do when facing the same alternatives in a real market (Molin and van Wee 2017; Brownstone et al. 2000). Only a few recent studies have used revealed preference surveys, i.e., data obtained from buyers of fuelefficient and alternative-fuel vehicles (Axsen et al. 2012; Axsen et al. 2015; Tal et al. 2013). Most such studies focused only on developing a better understanding of the variation in demographics and attitudinal values of current buyers of fuel-efficient and alternative-fuel vehicles, but not on nationwide potential market share estimations.

A new data-mining approach, ex-post counterfactual inference, was recently developed to estimate nationwide consumer demand for battery electric vehicles (BEVs) using revealed preference survey data from MY 2013 new car buyers (Dua et al. 2019). This approach aims to identify current adopter types, their reasons for adoption, potential adopters, size of the potential market, and factors that could induce potential buyers to adopt more fuel-efficient vehicles. This paper extends the approach to understand consumer demand for fuelefficient and alternative-fuel vehicles including HEVs, plug-in hybrid electric vehicles (PHEVs), and BEVs, using the past 11 years of revealed preference consumer survey data from MY 2005 to MY 2015, relating to more than 1 million respondents. This paper provides an assessment for (i) latent demand for all xEV types in each year; (ii) identifying helpful factors in achieving the estimated latent demand; (iii) linkage between latent demand, micro consumer-level factors, and exogenous macro factors.

\section{Data}

This study relies on data from a large-scale, nationally representative, revealed preference survey of new vehicle buyers, known as New Vehicle Experience Survey (NVES) conducted by Strategic Vision Incorporated. The paper analyzes 11 years of NVES data from MY 2005 to MY 2015. The NVES is sent out to new vehicle buyers within 3 months of their purchase in a particular model year. The total number of respondents who completed at least part of the survey in each model year is presented in Table 1. For this study, a subset of the total respondents from each year is selected,

Table 1 Sample size for each model year

\begin{tabular}{llc}
\hline Model year & $\begin{array}{l}\text { Total number } \\
\text { of respondents surveyed }\end{array}$ & $\begin{array}{l}\text { Sample size } \\
\text { used for analysis }\end{array}$ \\
\hline 2005 & 93,164 & 29,660 \\
2006 & 99,694 & 27,961 \\
2007 & 99,145 & 32,948 \\
2008 & 119,115 & 39,741 \\
2009 & 178,384 & 100,170 \\
2010 & 302,931 & 159,777 \\
2011 & 336,370 & 181,836 \\
2012 & 339,162 & 191,568 \\
2013 & 162,701 & 88,404 \\
2014 & 317,493 & 94,557 \\
2015 & 215,215 & 105,691 \\
\hline
\end{tabular}


based on the respondents who answered all the questions used in this analysis.

To understand the consumer's choice, two sets of attributes were used: (a) purchase motivations and (b) demographics. Surveying their purchase motivations, consumers rate, on a scale of one to five, the importance of a set of purchase considerations to their decision. A comprehensive list of variables used in this analysis combined across different model years is provided in Table 2. Similar to the criteria used in (Dua et al. 2019), for each model year, variables with a pairwise correlation of less than 0.6 were automatically selected for the analysis. Among groups of variables that have a pairwise correlation of more than 0.6 , only one representative variable is selected.

The demographic set of variables corresponds to questions related to respondents' age, income, children, and total number of other vehicles in their household. The reported age is transformed into a continuous scale with a range from 1 to 5 . The reported income is represented as a logarithmic scale and then transformed into a continuous scale with a range from 1 to 5 .

The NVES data also provides weightings that correspond to the ratio of the number of buyers for each make and model in the national market to the number of respondents for the same make and model in the survey.

\section{Methodology}

Heterogeneity in the xEV market

To account for heterogeneity among xEV buyers, the current $\mathrm{xEV}$ buyers are segmented into distinct profiles using k-means clustering, as shown in Fig. 1(a). The segmentation process involving k-means clustering was based on the methodology followed in (Dua et al. 2019).

Identifying similarities and differences among different buyer types

The major differences, and similarities, between the different $\mathrm{xEV}$ segments as against their respective purchase motivations and demographics relative to a representative gasoline vehicle cluster were obtained by comparing the utility scores for each $\mathrm{xEV}$ buyer group. The utility score, calculated using a stepwise multinomial logistic regression (MLR), was based on the methodology followed in (Dua et al. 2019).

Table 2 List of variables used for the analysis for each model year

\begin{tabular}{|c|c|c|c|c|}
\hline \multicolumn{4}{|l|}{ Purchase reason } & \multirow{2}{*}{$\begin{array}{l}\text { Demographics } \\
\text { Total Number } \\
\text { of children }\end{array}$} \\
\hline Advertising and promotion & Handling & $\begin{array}{l}\text { Past experience } \\
\text { with brand }\end{array}$ & $\begin{array}{l}\text { Convenience } \\
\text { of controls }\end{array}$ & \\
\hline $\begin{array}{l}\text { Advice of friends and } \\
\text { relatives }\end{array}$ & Income & Reputation of manufacturer & $\begin{array}{l}\text { Costs of operations and } \\
\text { repair }\end{array}$ & $\begin{array}{c}\text { Total other vehicles } \\
\text { owned/leased }\end{array}$ \\
\hline Audio/video system & Interest rate/credit terms & Technical innovation & Exterior color & Income \\
\hline Cargo capacity & Interior roominess & Total children in household & Seating capacity & Age \\
\hline Dealer reputation & Leasing terms & $\begin{array}{l}\text { Total other vehicles } \\
\text { owned/leased }\end{array}$ & Power pickup & \\
\hline Discount/rebates/incentives & Car reviews & Towing capacity & Prestige & \\
\hline Ease of customization & Navigation system & Price/value for money & Price & \\
\hline Ease of front-seat entry & $\begin{array}{l}\text { Environmental } \\
\text { friendliness }\end{array}$ & Warranty coverage & Size/weight of vehicle & \\
\hline Performance & Exterior styling & Availability of AWD & Interior options & \\
\hline Fuel economy & Reliability & Country of manufacture & Quietness & \\
\hline Fun to drive & Safety & Availability of RWD & Design for theft protection & \\
\hline Future trade-in/resale value & Seating comfort & A well-made vehicle & Quality of workmanship & \\
\hline Vehicle image & Interior versatility & & & \\
\hline
\end{tabular}


Identifying Different Types of XEV Buyers

Q xEV-1 Buyers $Q$ xEV-2 Buyers

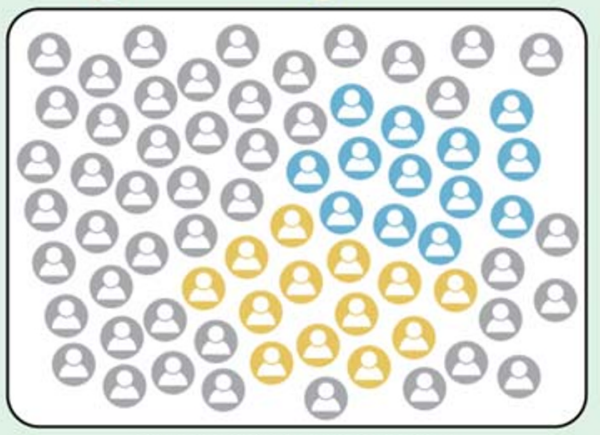

Segment $x E V$ buyers using

k-Means clustering

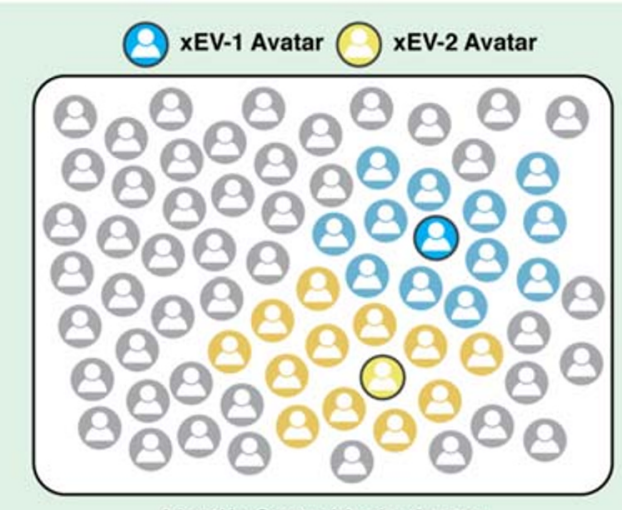

Identify Centroid, aka Avatar

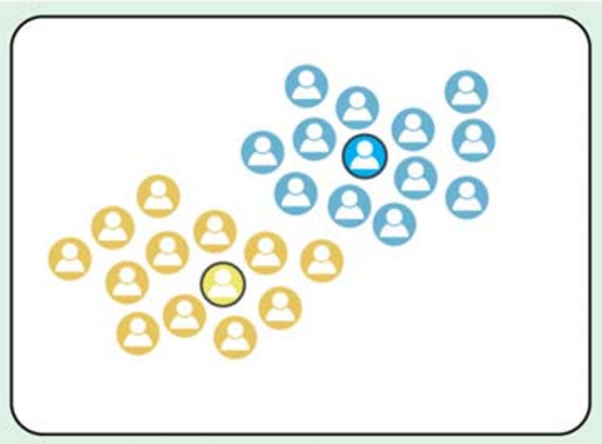

Identify Factors Separating the Different xEV Clusters Using Stepwise Multinomial Logit Regression
Identifying Potential xEV Buyers

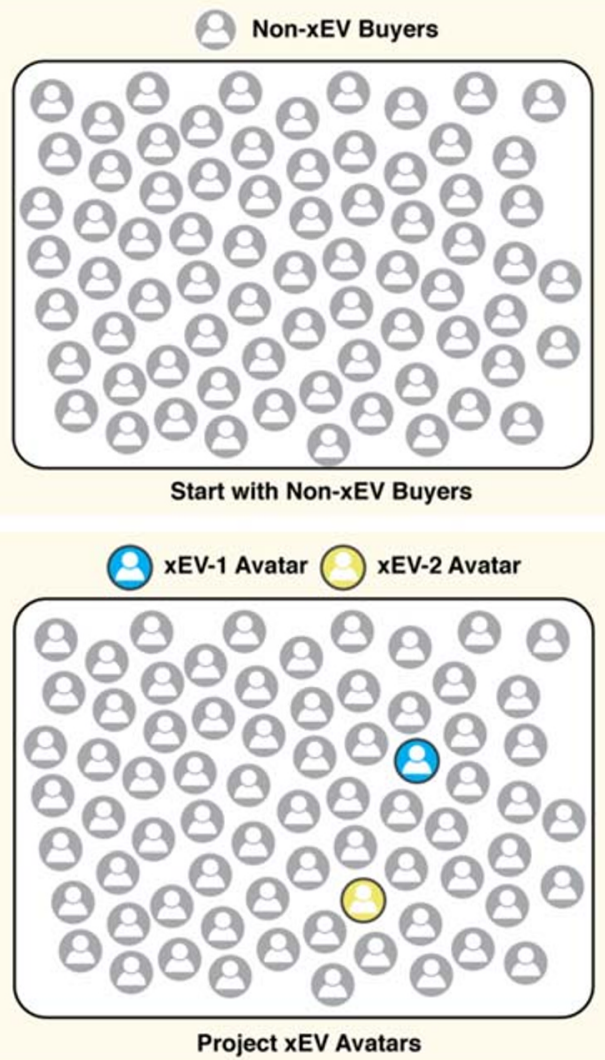

Project xEV Avatars

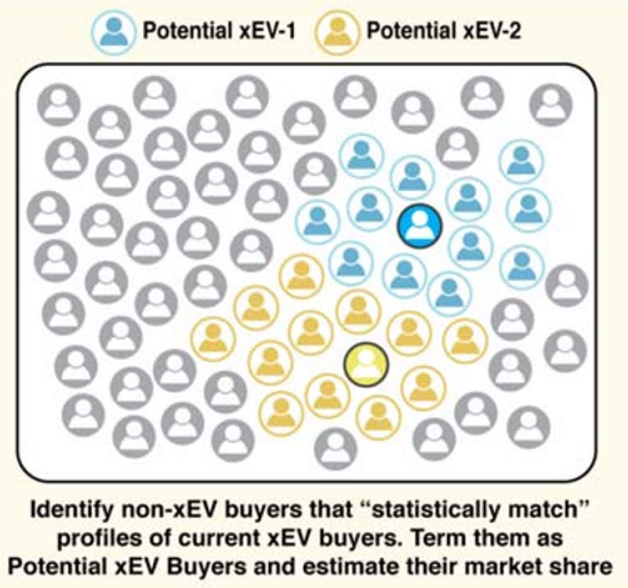

Fig. 1 Identifying types and potential xEV buyers. This figure, adapted from (Dua et al. 2019), sets out the approach for identifying a different types of $\mathrm{xEV}$ buyers and $\mathbf{b}$ potential $\mathrm{xEV}$ buyers

\section{Valuation gap}

The valuation gap represents the difference between non-xEV and $\mathrm{xEV}$ consumers' valuation for purchase motivations. As described in the data section, consumers are asked to rate on a scale of one to five the importance of a particular set of factors to their purchase decision. Thus, the valuation gap for a particular factor is the difference in the sales-weighted value for that factor between non-xEV buyers and xEV buyers. 
It is calculated using the following formula:

Valuation gap $=\left(\frac{\sum_{i=1}^{N_{i}} w_{i} X_{i}}{\sum_{i=1}^{N_{i}} w_{i}}\right)_{\mathrm{non}-\mathrm{xEV}}-\left(\frac{\sum_{j=1}^{N_{j}} w_{j} X_{j}}{\sum_{j=1}^{N_{j}} w_{j}}\right)_{\mathrm{xEV}}$

where

$i$ denotes non-xEV respondent,

$j$ denotes $\mathrm{xEV}$ respondent,

$N$ denotes the maximum number of respondents,

$X$ denotes the consumer valuation for a purchase motivation, and

$w$ represents weight associated with the respondent.

Identifying potential $\mathrm{xEV}$ buyers, size of potential market, and factors that can induce switching

Identification of the potential $\mathrm{xEV}$ buyers, size of the potential market, and the factors that could induce them to switch was based on the data-mining methodology followed in (Dua et al. 2019).

\section{Results and discussion}

Similarities and differences among various xEV segments

As shown in Fig. 2, fuel economy, environmental friendliness, and technical innovation are the three most important purchase motivations for all the $\mathrm{xEV}$ clusters relative to the representative gasoline vehicle cluster. On the other hand, value for money, exterior styling, safety, reliability, and handling are more important for the representative gasoline vehicle cluster. Among the two hybrid clusters, HEV-1 buyers have fewer expectations from their vehicle. Table 3 shows that both HEV clusters purchase similar types of vehicles, but as seen in Fig. 2, they have different

Fig. 2 Similarities and differences among various xEV segments. This figure shows Venn diagrams highlighting the similarities and differences between distinct a HEV, b PHEV, and $\mathbf{c} \mathrm{BEV}$ clusters relative to a representative gasoline vehicle cluster

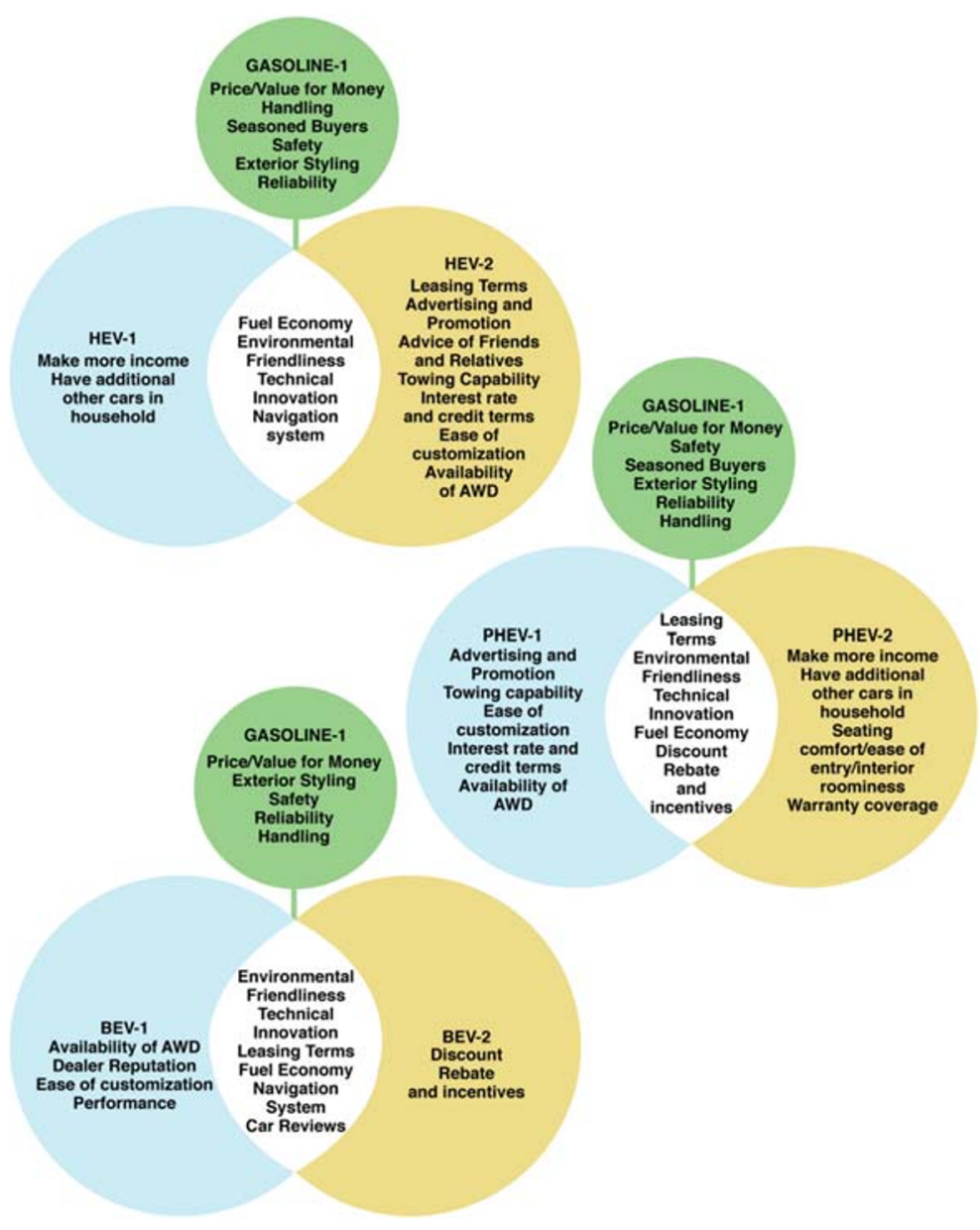


Table 3 Top 10 models purchased by xEV fuel type buyers

\begin{tabular}{llllll}
\hline HEV-1 & HEV-2 & PHEV-1 & PHEV-2 & BEV-1 & BEV-2 \\
\hline Toyota Prius & Toyota Prius & Chevrolet Volt & Chevrolet Volt & Tesla Model S & Nissan Leaf \\
Toyota Prius c & Toyota Prius c & Ford Fusion Plug-in & Ford Fusion Plug-in & Nissan Leaf & Fiat 500e \\
Toyota Prius v & Toyota Camry Hybrid & Ford C-MAX Energi & Ford C-MAX Energi & Fiat 500e & Chevrolet Spark EV \\
Toyota Camry Hybrid & Toyota Prius v & Toyota Prius Plug-in & Toyota Prius Plug-in & Mercedes BEV & Tesla Model S \\
Ford Fusion Hybrid & Lexus CT200h & & Honda Accord Plug-in & Ford Focus Electric & BMW i3 Hatchback \\
& & & Hybrid Sedan & & \\
\hline
\end{tabular}

expectations from their vehicle, highlighting the heterogeneity among consumers. The BEV and PHEV buyer clusters also care about leasing terms, which to some extent lowers risk associated with uncertain resale value, battery decay, and rapid technology improvements.

Potential buyers and size of market

The potential market share for all xEV types from MY 2005 to MY 2015 is shown in Fig. 3. The total market share for $\mathrm{xEVs}$ combined shows a potential to increase by an average factor of almost three over the past 11 model years. To understand the variation of the estimated potential market share, the non-xEV and xEV consumers' valuation of purchase motivations was compared. This is because the potential market share is estimated by identifying non-xEV buyers that have purchase motivations and demographics very similar to

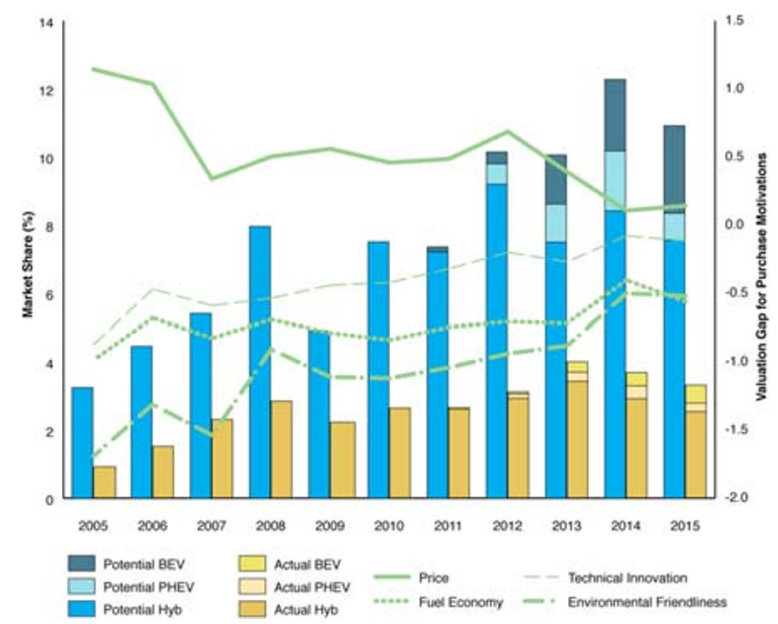

Fig. 3 Variation of (i) actual and potential market share for $\mathrm{xEVs}$ on primary axis and (ii) difference between non-xEV and xEV consumers' valuation of purchase motivations on secondary axis. Since valuation gap is a difference in the consumer ratings, it has no units those of xEV buyers. Figure 2 had revealed that fuel economy, environmental friendliness, technical innovation, and price are four important purchase motivations that set apart xEV buyers. Thus, in any model year, as non-xEV and $\mathrm{xEV}$ consumers come close in terms of their valuation of these purchase motivations, a higher potential market share for $\mathrm{xEVs}$ would be estimated, as is confirmed in Fig. 3. The estimated potential market share for $\mathrm{xEVs}$ exhibits strong positive correlation with the valuation gap for fuel economy (correlation coefficient, $r=0.79)$, environmental friendliness $(r=0.91)$, and technical innovation $(r=0.89)$ and strong negative correlation with price $(r=-0.75)$.

Figure 4 examines the variation in the valuation gap for fuel economy, environmental friendliness, technical innovation, and price with exogenous macro factors such as the CAFE target and gasoline price. The CAFE target was found to exhibit a strong positive correlation with the valuation gap for environmental friendliness

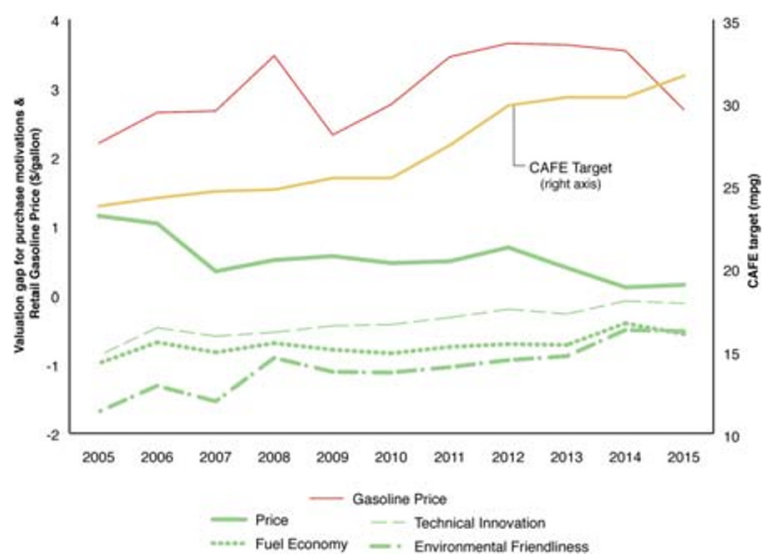

Fig. 4 Variation of (i) valuation gap for fuel economy, technical innovation, environmental friendliness, and price; (ii) retail gasoline price; and (iii) CAFE target. The retail gasoline price is obtained from U.S. EIA (EIA 2016), and the CAFE target is obtained from NHTSA (NHTSA 2016). Since valuation gap is a difference in the consumer ratings, it has no units 
$(r=0.83)$, technical innovation $(r=0.89)$, and fuel economy $(r=0.69)$.

To meet the CAFE targets, automakers have been adding innovative fuel-efficient and environmentally friendly technologies to non-xEVs. Non-xEV consumers may experience increased utility from driving their newly purchased vehicle, compared with their previous vehicle, before taking the survey. This could have led to non-xEV consumers' higher valuation of technical innovation, fuel economy, and environmental friendliness as important purchase motivations over successive model years (as shown in Fig. A4 in the supplementary information). On the other hand, the $x E V$ consumers' valuation of these purchase motivations is decreasing over time (also shown in Fig. A4 in the supplementary information). This could be because $\mathrm{xEV}$ technologies, especially HEVs, have been on the market for more than a decade and are increasingly becoming mainstream. In addition, demand-side policies providing financial and non-financial incentives have made HEVs more affordable and accessible for a higher fraction of mainstream consumers. Moreover, with the arrival of newer $\mathrm{xEV}$ technologies such as PHEVs and BEVs, the HEV consumers' valuation for the previously mentioned purchase reasons decreases, as they are not buying the most fuel-efficient and environmentally friendly vehicle available on the market. Among xEVs, the market share for HEVs is almost an order of magnitude higher, and thus the overall trend for $\mathrm{xEV}$ consumers' valuation follows the trend for HEV consumers' valuation.

Over the study period, as the CAFE targets kept rising, the valuation gap between $\mathrm{xEVs}$ and nonxEVs kept decreasing, in part because the sticker price between these two types of cars kept narrowing. This is because as a result of the GHG/CAFE standards, the price for non-xEVs is increasing due to the addition of fuel efficiency-improvement technologies. On the other hand, battery costs, a major contributor to $\mathrm{xEVs}$ costs, are decreasing with time through learning-by-doing, economies of scale, and vertical chain integration. The price premium between non-xEVs and xEVs is thus decreasing with time. Correspondingly, the valuation gap for price is decreasing, exhibiting a moderate negative correlation with the CAFE target $(r=-0.64)$, resulting in higher estimated potential market share.

In summary, a combination of supply-side and demand-side policies serves as a useful tool if policymakers are seeking to nudge non-xEV buyers' purchase motivations closer to those of xEV buyers.

The gasoline price also exhibits a moderate positive correlation with the valuation gap for fuel economy ( $r=$ $0.53)$, technical innovation $(r=0.60)$, and environmental friendliness $(r=0.59)$. As gasoline prices go up, fuel economy, environmental friendliness, and, to some extent, even technical innovation also become important to non-xEV buyers. The moderate effect of the gasoline price on the valuation gap for purchase motivations could be because of supply-side policies such as GHG/ CAFE targets and the ZEV mandate. Such policies have the potential to reduce the impact of a low gasoline price on consumers' purchase motivations by requiring automakers to produce and sell increasingly fuel-efficient vehicles. In the absence of such policies, gasoline prices could have had a stronger impact on consumers' purchase motivations.

Factors that can induce switching

To identify factors that could induce potential xEV buyers to adopt XEVs, a comparison is made between actual xEV buyers with potential xEV buyers. Comparing their profiles helps identify further steps that private and public sector entities could deploy to encourage potential xEV buyers to become actual $\mathrm{xEV}$ buyers. Attention is given to HEV-1, PHEV-1, PHEV-2, BEV-1, and BEV-2 buyers only, as those groups show the maximum scope for growth, as shown in Table A3 in the supplementary information. Table 4 summarizes the differences between potential and actual xEV buyers, and factors that private and public sectors might consider to facilitate adoption. For details on how the factors are identified, please refer to the "Methodology" section.

Consider potential BEV-2 buyers as an example. Figure 2 has revealed that BEV-2 buyers care about environmental friendliness, technical innovation, leasing terms, fuel economy, and rebates. Non-BEV buyers who also care about such factors, but care less about other factors, are likely to switch to BEV-2. As highlighted in Table 4, potential BEV-2 buyers also care more about these factors compared with Gasoline-1 buyers. In spite of caring more about these factors than average Gasoline-1 buyers, these potential BEV-2 buyers still end up buying a gasoline vehicle.

A way forward can now be seen. Such consumers either need encouragement to care even more about such 
Table 4 Adoptive factors. This table shows factors that can induce potential $\mathrm{xEV}$ buyers to adopt $\mathrm{xEV}$. These findings were obtained by comparing potential $\mathrm{xEV}$ buyers with actual $\mathrm{xEV}$ and
Gasoline-1 buyers. The factors are listed in order of ranking. See Figs. A5-A9 in the supplementary information for detailed results
Factors and features where potential xEV buyers are closer to actual xEV buyers

Relative to Gasoline-1 Relative to Gasoline-1 buyers, buyers, both favor both are willing to trade off
Factors and features where potential xEV buyers are closer to Gasoline-1 buyers

Relative to actual xEV Relative to actual xEV buyers, buyers, both favor both are willing to trade off

\begin{tabular}{|c|c|c|c|c|}
\hline HEV-1 (MY 2015) & $\begin{array}{l}\text { - Fuel economy } \\
\text { - Environmental } \\
\text { friendliness } \\
\text { - Past experience with } \\
\text { brand } \\
\text { - Navigation system } \\
\text { - Technical innovation }\end{array}$ & $\begin{array}{l}\text { - Value for money } \\
\text { - Fun to drive } \\
\text { - Exterior styling } \\
\text { - Handling } \\
\text { - Availability of AWD } \\
\text { Demographics* } \\
\text { - Younger } \\
\text { - Lower income }\end{array}$ & $\begin{array}{l}\text { - Dealer reputation } \\
\text { - Safety }\end{array}$ & \\
\hline PHEV-1 (MY 2015) & $\begin{array}{l}\text { - Leasing terms } \\
\text { - Environmental } \\
\text { friendliness } \\
\text { - Interest rate/credit } \\
\text { terms } \\
\text { - Car reviews } \\
\text { - Discounts, rebates, } \\
\text { and incentives }\end{array}$ & $\begin{array}{l}\text { - Reliability } \\
\text { - Exterior styling } \\
\text { - Price/value for money } \\
\text { - Manufacturer's reputation } \\
\text { - Fun to drive } \\
\text { Demographics* } \\
\text { - Younger } \\
\text { - Lower income }\end{array}$ & $\begin{array}{l}\text { - Safety } \\
\text { - Performance } \\
\text { - Handling } \\
\text { - Interior roominess }\end{array}$ & $\begin{array}{l}\text { - Advertising and promotion } \\
\text { - Ease of customization } \\
\text { - Advice of friends and relatives } \\
\text { - Towing capability } \\
\text { - Availability of AWD } \\
\text { - Fuel economy }\end{array}$ \\
\hline PHEV-2 (MY 2015) & $\begin{array}{l}\text { - Environmental } \\
\text { friendliness } \\
\text { - Technical innovation } \\
\text { - Fuel economy } \\
\text { - Discounts, rebates, } \\
\text { and incentives } \\
\text { - Performance }\end{array}$ & $\begin{array}{l}\text { - Price/value for money } \\
\text { - Handling } \\
\text { - Safety } \\
\text { - Ease of customization } \\
\text { - Towing capability } \\
\text { Demographics* } \\
\text { - Younger }\end{array}$ & $\begin{array}{l}\text { - Interior roominess } \\
\text { - Dealer reputation } \\
\text { - Manufacturer } \\
\text { reputation }\end{array}$ & \\
\hline BEV-1 (MY 2015) & $\begin{array}{l}\text { - Environmental } \\
\text { friendliness } \\
\text { - Technical innovation } \\
\text { - Navigation system } \\
\text { - Fun to drive } \\
\text { - Car reviews }\end{array}$ & $\begin{array}{l}\text { - Price/value for money } \\
\text { - Handling } \\
\text { - Reliability } \\
\text { - Exterior styling } \\
\text { - Interest rate/credit terms } \\
\text { Demographics* } \\
\text { - Younger }\end{array}$ & - Seating comfort & $\begin{array}{l}\text { Demographics* } \\
\text { - Lower income }\end{array}$ \\
\hline BEV-2 (MY 2015) & $\begin{array}{l}\text { - Leasing terms } \\
\text { - Environmental } \\
\text { friendliness } \\
\text { - Technical innovation } \\
\text { - Discounts, rebates, } \\
\text { and incentives } \\
\text { - Fuel economy }\end{array}$ & $\begin{array}{l}\text { - Price/value for money } \\
\text { - Reliability } \\
\text { - Handling } \\
\text { - Dealer reputation } \\
\text { - Interior options } \\
\text { Demographics* } \\
\text { - Younger } \\
\text { - Lower income }\end{array}$ & $\begin{array}{l}\text { - Exterior styling } \\
\text { - Warranty coverage } \\
\text { - Future trade-in/resale } \\
\text { value }\end{array}$ & - Car reviews \\
\hline
\end{tabular}

*Demographic differences between potential and actual buyers

This table identifies the levers that manufacturers can use to promote $\mathrm{xEV}$ adoption to meet the targets set by the policymakers. It is to highlight that the consumers could potentially buy xEVs provided the features they care about are offered in xEVs, unlike claims by some manufacturers that consumers do not want to buy xEVs (Huffman 2020)

purchase motivations or need the utility they derive from gasoline vehicles, which current BEVs do not provide. For example, as highlighted in Table 4, these potential BEV-2 buyers do care about exterior styling, warranty coverage, and resale value, as do gasoline vehicle buyers, and more so than actual BEV-2 buyers. Providing these features or capabilities in BEVs could encourage potential BEV-2 buyers to adopt BEVs.

To achieve market share beyond the estimated potential, factors and features from which mainstream 
gasoline vehicle buyers derive high utility, such as value for money (Breetz and Salon 2018), reliability (Egbue and Long 2012) and handling in inclement weather (through adding features such as all-wheel drive/winter tire options (Consumer Reports 2015)), would also have to be offered, while ensuring that the vehicle cost stays in check. Currently, both actual and potential xEV buyers are willing to trade these factors and features for fuel economy, environmental friendliness, and technical innovation. But future mainstream xEV buyers, beyond the identified potential $\mathrm{xEV}$ buyers, may not be willing to make that trade-off. In the long term, therefore, providing such features or capabilities in xEVs would be vital in bringing about this transition.

Can all xEV sales grow simultaneously?

Our analysis in this paper allows for optimistic growth for all fuel types. An obvious question arises: Would the different $x E V$ fuel types cannibalize each other, or could they all grow simultaneously? As can be seen in Fig. 5, for MY 2015 , the majority $(\sim 70 \%)$ of potential xEV buyers is composed of fuel economy-conscious conventional gasoline vehicle buyers. All xEV fuel types, therefore, can grow simultaneously at the expense of gasoline vehicles. However, because of the federal GHG/CAFE emission standards, gasoline vehicles, too, are becoming increasingly fuel-efficient. Moreover, due to current low gasoline prices, the driving force encouraging fuel economy-conscious gasoline vehicle buyers to adopt even more fuel-efficient $\mathrm{xEVs}$ remains limited. As far as competition among xEV fuel types is concerned, since all the xEV fuel types are competing

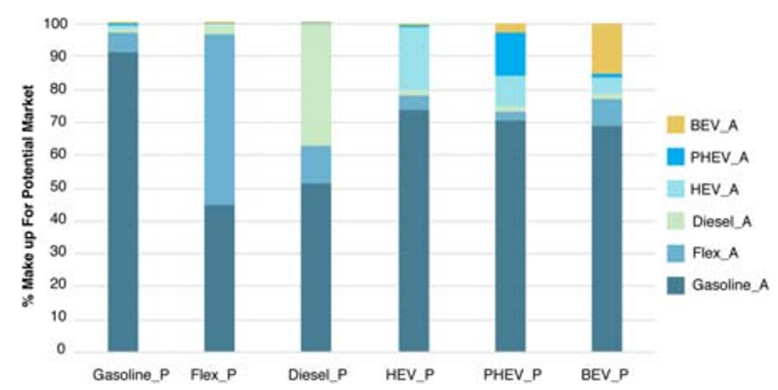

Fig. 5 Percentage makeup for potential market for each fuel type, where "_P" stands for potential and "A" stands for actual. To interpret the plot quickly, look, for example, at the column corresponding to PHEV-P, where $70 \%$ of this column is composed of Gasoline_A. This means $70 \%$ of potential PHEV buyers are composed of actual gasoline vehicle buyers
Table 5 Top 10 models purchased by potential xEV fuel type buyers

\begin{tabular}{|c|c|c|}
\hline Potential HEV & Potential PHEV & Potential BEV \\
\hline Toyota Camry & Kia Soul & Toyota Corolla \\
\hline Toyota Corolla & Nissan Altima Sedan & Toyota Camry \\
\hline $\begin{array}{l}\text { Honda Civic } \\
\text { Sedan }\end{array}$ & $\begin{array}{l}\text { Volkswagen Jetta } \\
\text { Sdn/GLI Sdn }\end{array}$ & $\begin{array}{l}\text { Subaru Outback } \\
\text { Wgn }\end{array}$ \\
\hline $\begin{array}{l}\text { Honda Accord } \\
\text { Sedan }\end{array}$ & Honda Civic Sedan & Toyota RAV4 \\
\hline $\begin{array}{l}\text { Nissan Altima } \\
\text { Sedan }\end{array}$ & Toyota Prius & Kia Forte Sedan \\
\hline $\begin{array}{l}\text { Hyundai Elantra } \\
\text { Sedan }\end{array}$ & Hyundai Sonata & Nissan Rogue \\
\hline Honda Fit & Ford Fusion & $\begin{array}{l}\text { Chevrolet } \\
\text { Equinox }\end{array}$ \\
\hline Hyundai Sonata & Honda Accord Sedan & Mazda CX-5 \\
\hline Honda CR-V & Chevrolet Camaro & $\begin{array}{l}\text { Nissan Altima } \\
\text { Sedan }\end{array}$ \\
\hline Chevrolet Cruze & Ford Edge & $\begin{array}{l}\text { Honda Accord } \\
\text { Sedan }\end{array}$ \\
\hline
\end{tabular}

directly with fuel-efficient gasoline vehicles, as shown in Table 5, they indirectly compete with each other. A buyer switching from a fuel-efficient gasoline vehicle to a BEV is one who did not switch to a PHEV.

\section{Conclusion}

In summary, the potential market share for different $x E V$ fuel types has been estimated, using the past 11 years of consumer profile data. A counterfactual scenario under optimistic growth conditions reveals that the $\mathrm{xEV}$ fuel types had the potential to reach around $11 \%$ of the US new vehicle sales in MY 2015. Instead, xEV fuel types captured only one-third of this market. Key to fulfilling the remaining potential is the public and private sector's ability to encourage fuel economy-conscious conventional gasoline vehicle buyers to step up to even more fuel-efficient xEVs.

These potential consumers want features and factors such as exterior styling, safety, warranty coverage, and better resale value. ${ }^{1}$ Such features are currently more commonly found in conventional gasoline vehicles than

\footnotetext{
${ }^{1}$ With regard to styling, it is worth noting that BEV designs tend to stand out and could be less appealing (Graham-Rowe et al. 2012). With regard to hybrids, Toyota Prius is the main selling hybrid in the USA with its own unique style (Toyota 2017). With regard to safety, it could just be a perception and/or familiarity issue (Van den Bossche 1994).
} 
xEVs. Manufacturers could integrate the same features and factors into xEVs, which could drive up sales, but adding these desirable features may increase the upfront cost of xEVs - and that could have a negative impact on growth, since potential buyers tend to have lower incomes.

The CAFE target exhibits a strong positive correlation with the valuation gap for purchase motivations of fuel economy, technical innovation, and environmental friendliness. These are important purchase motivations for actual xEV buyers. Because of the CAFE targets, the non-xEV vehicle offerings are becoming increasingly more fuel-efficient and environmentally friendly. The increased utility derived from the addition of these features could be leading to higher valuation of related purchase motivations by non-xEV buyers. On the other hand, demand-side policies have made xEVs more accessible to mainstream consumers. This may be leading to $\mathrm{xEV}$ consumers' lower valuation of these purchase motivations over time. Consequently, the combined effect of these supply-side and demand-side policies could be to bring the purchase motivations of non$x E V$ buyers closer to those of $x E V$ buyers.

Different $x E V$ fuel types compete indirectly over similar segments of fuel economy-conscious conventional gasoline vehicle buyers. Despite that, the analysis finds that the different $\mathrm{xEV}$ fuel types have the potential to grow up to three times their current market size. Because of GHG/CAFE targets, however, conventional gasoline vehicles are also becoming increasingly more fuel-efficient. In the short term, consumers have more fuel-efficient options. Encouraging them to choose the most fuel-efficient xEVs at a time of low gasoline prices remains a challenge.

In the long term, as the CAFE targets become more stringent, conventional vehicle costs would keep rising following the addition of fuel-efficiency technologies. The increase in the stringency of CAFE targets coupled with higher fines and allowance of fleet pooling is already driving vehicle electrification efforts among manufacturers in Europe (Sigal 2020; Dawson and Sachgau 2019; McGee and Campbell 2019). While in the USA and China, higher CAFE credits for selling PEVs are encouraging manufacturers to introduce more PEV models in their line-up (Ou et al. 2019; Jenn et al. 2016; Jenn et al. 2019). In addition, as battery costs are reduced, through learning-by-doing, supply chain integration, and economies of scale, xEVs could become an economically feasible option for automakers to meet the mandated standards and for consumers when choosing among different fuel-efficient vehicles. Thus, policy instruments such as the CAFE/GHG emission standards and ZEV mandate, combined with demandside support policies (such as financial and nonfinancial incentives including subsidies, registration fee waivers, free parking, and toll road fee waivers), represent viable tools if policymakers wish to nudge consumers toward xEVs.

\section{Compliance with ethical standards}

Conflict of interest The authors declare that they have no conflict of interest.

Open Access This article is licensed under a Creative Commons Attribution 4.0 International License, which permits use, sharing, adaptation, distribution and reproduction in any medium or format, as long as you give appropriate credit to the original author(s) and the source, provide a link to the Creative Commons licence, and indicate if changes were made. The images or other third party material in this article are included in the article's Creative Commons licence, unless indicated otherwise in a credit line to the material. If material is not included in the article's Creative Commons licence and your intended use is not permitted by statutory regulation or exceeds the permitted use, you will need to obtain permission directly from the copyright holder. To view a copy of this licence, visit http://creativecommons.org/licenses/by/4.0/.

\section{References}

National Highway Traffic Safety Administration (2019) Corporate average fuel economy. https://www.nhtsa. gov/laws-regulations/corporate-average-fuel-economy. Accessed January 2018.

United States Environmental Protection Agency (2018). Regulations for emissions from vehicles and engines. https://www.epa.gov/regulations-emissions-vehicles-andengines/regulations-greenhouse-gas-emissions-passengercars-and. Accessed November 2018.

Union of Concerned Scientists (2016). What is ZEV? https://www. ucsusa.org/clean-vehicles/california-and-westernstates/what-is-zev\#.XFmU61UzaUk. Accessed January 2017.

Center for Climate and Energy Solutions (2019). U.S. clean vehicle policies and incentives. https://www.c2es. org/document/zev-program/. Accessed January 2019.

Gallagher, K. S., \& Muehlegger, E. (2011). Giving green to get green? Incentives and consumer adoption of hybrid vehicle 
technology. Journal of Environmental Economics and Management, 61(1), 1-15. https://doi.org/10.1016/j. jeem.2010.05.004.

Peterson, S. B., \& Michalek, J. J. (2013). Cost-effectiveness of plug-in hybrid electric vehicle battery capacity and charging infrastructure investment for reducing US gasoline consumption. Energy Policy, 52, 429-438. https://doi.org/10.1016/j. enpol.2012.09.059.

Al-Alawi, B. M., \& Bradley, T. H. (2013). Review of hybrid, plugin hybrid, and electric vehicle market modeling studies. Renewable and Sustainable Energy Reviews, 21, 190-203. https://doi.org/10.1016/j.rser.2012.12.048.

Rezvani, Z., Jansson, J., \& Bodin, J. (2015). Advances in consumer electric vehicle adoption research: a review and research agenda. Transportation Research Part D: Transport and Environment, 34, 122-136. https://doi.org/10.1016/j. $\operatorname{trd} .2014 .10 .010$.

Carley, S., Krause, R. M., Lane, B. W., \& Graham, J. D. (2013). Intent to purchase a plug-in electric vehicle: a survey of early impressions in large US cites. Transportation Research Part D: Transport and Environment, 18, 39-45. https://doi. org/10.1016/j.trd.2012.09.007.

Egbue, O., \& Long, S. (2012). Barriers to widespread adoption of electric vehicles: an analysis of consumer attitudes and perceptions. Energy Policy, 48, 717-729. https://doi. org/10.1016/j.enpol.2012.06.009.

Krupa, J. S., Rizzo, D. M., Eppstein, M. J., Brad Lanute, D., Gaalema, D. E., Lakkaraju, K., \& Warrender, C. E. (2014). Analysis of a consumer survey on plug-in hybrid electric vehicles. Transportation Research Part A: Policy and Practice, 64, 14-31. https://doi.org/10.1016/j. tra.2014.02.019.

Lieven, T., Mühlmeier, S., Henkel, S., \& Waller, J. F. (2011). Who will buy electric cars? An empirical study in Germany. Transportation Research Part D: Transport and Environment, 16(3), 236-243. https://doi.org/10.1016/j. $\operatorname{trd} .2010 .12 .001$.

Ščasný, M., Zvěřinová, I., \& Czajkowski, M. (2018). Electric, plug-in hybrid, hybrid, or conventional? Polish consumers' preferences for electric vehicles. Energy Efficiency, 11(8), 2181-2201. https://doi.org/10.1007/s12053-018-9754-1.

Bunch, D. S., Bradley, M., Golob, T. F., Kitamura, R., \& Occhiuzzo, G. P. (1993). Demand for clean-fuel vehicles in California: a discrete-choice stated preference pilot project. Transportation Research Part A: Policy and Practice, 27(3), 237-253. https://doi.org/10.1016/0965-8564(93)90062-P.

Chorus, C. G., Koetse, M. J., \& Hoen, A. (2013). Consumer preferences for alternative fuel vehicles: comparing a utility maximization and a regret minimization model. Energy Policy, 61, 901-908. https://doi.org/10.1016/j. enpol.2013.06.064.

Ewing, G., \& Sarigöllü, E. (2000). Assessing consumer preferences for clean-fuel vehicles: a discrete choice experiment. Journal of Public Policy \& Marketing, 19(1), 106-118. https://doi.org/10.1509/jppm.19.1.106.16946.

Hackbarth, A., \& Madlener, R. (2013). Consumer preferences for alternative fuel vehicles: a discrete choice analysis. Transportation Research Part D: Transport and Environment, 25, 5-17. https://doi.org/10.1016/j. $\operatorname{trd}$.2013.07.002.
Hoen, A., \& Koetse, M. J. (2014). A choice experiment on alternative fuel vehicle preferences of private car owners in the Netherlands. Transportation Research Part A: Policy and Practice, 61, 199-215. https://doi.org/10.1016/j. tra.2014.01.008.

Molin, E., \& van Wee, B. (2017). Consumer preferences for electric vehicles: a literature review AU - Liao, Fanchao. Transport Reviews, 37(3), 252-275. https://doi.org/10.1080 /01441647.2016.1230794.

Liao, F., Molin, E., Timmermans, H., \& van Wee, B. (2019). Consumer preferences for business models in electric vehicle adoption. Transport Policy, 73, 12-24. https://doi. org/10.1016/j.tranpol.2018.10.006.

Brownstone, D., Bunch, D. S., \& Train, K. (2000). Joint mixed logit models of stated and revealed preferences for alternative-fuel vehicles. Transportation Research Part B: Methodological, 34(5), 315-338. https://doi.org/10.1016 /S0191-2615(99)00031-4.

Axsen, J., TyreeHageman, J., \& Lentz, A. (2012). Lifestyle practices and pro-environmental technology. Ecological Economics, 82, 64-74. https://doi.org/10.1016/j. ecolecon.2012.07.013.

Axsen, J., Bailey, J., \& Castro, M. A. (2015). Preference and lifestyle heterogeneity among potential plug-in electric vehicle buyers. Energy Economics, 50, 190-201. https://doi. org/10.1016/j.eneco.2015.05.003.

Tal, G., Nicholas, M., Woodjack, J., Scrivano, D. (2013) Who is buying electric cars in California? exploring household and vehicle fleet characteristics of new plug-in vehicle owners. https://trid.trb.org/view.aspx?id=1263023.

Dua, R., White, K., \& Lindland, R. (2019). Understanding potential for battery electric vehicle adoption using large-scale consumer profile data. Energy Reports, 5, 515-524. https://doi.org/10.1016/j.egyr.2019.04.013.

EIA (2016). U.S. Retail gasoline prices. http://www.eia. gov/dnav/pet/hist/LeafHandler.ashx?n=PET\&s=EMM EPM0_PTE_NUS_DPG\&f=M.

NHTSA (2016). Fleet Fuel Economy Performance Report. https://one.nhtsa.gov/cafe_pic/CAFE_PIC_fleet_LIVE.html.

Breetz, H. L., \& Salon, D. (2018). Do electric vehicles need subsidies? Ownership costs for conventional, hybrid, and electric vehicles in 14 U.S. cities. Energy Policy, 120, 238249. https://doi.org/10.1016/j.enpol.2018.05.038.

Consumer Reports (2015). Do you really need awd in the snow? https:/www.consumerreports.org/cro/magazine/2015/09/doyou-really-need-awd-in-the-snow/index.htm.

Huffman, M. (2020). Subaru CEO says U.S. consumers don't want electric vehicles. https://www.consumeraffairs. $\mathrm{com} /$ news/subaru-ceo-says-us-consumers-dont-wantelectric-vehicles-012020.html.

Graham-Rowe, E., Gardner, B., Abraham, C., Skippon, S., Dittmar, H., Hutchins, R., \& Stannard, J. (2012). Mainstream consumers driving plug-in battery-electric and plug-in hybrid electric cars: a qualitative analysis of responses and evaluations. Transportation Research Part A: Policy and Practice, 46(1), 140-153. https://doi.org/10.1016 j.tra.2011.09.008.

Toyota (2017). The evolution of the Prius. https://global. toyota/en/prius20th/evolution/.

Van den Bossche, P. (1994). Safety considerations for electric vehicles. https://etec.vub.ac.be/publications/evs12vdb.pdf. 
Sigal, P. (2020). How automakers plan to avoid CO2 fines in Europe. https://europe.autonews.com/automakers/howautomakers-plan-avoid-co2-fines-europe.

Dawson, C., Sachgau, O. (2019). Europe's tough emissions rules come with $\$ 39$ billion threat. https://www.bloomberg. com/news/articles/2019-06-26/europe-s-tough-newemissions-rules-come-with-39-billion-threat.

McGee, P., Campbell, P. (2019). Fiat Chrysler pools fleet with Tesla to avoid EU emissions fines. https://www.ft. com/content/7a3c8d9a-57bb-11e9-a3db-1 fe89bedc16e.

Ou, S., Hao, X., Lin, Z., Wang, H., Bouchard, J., He, X., Przesmitzki, S., Wu, Z., Zheng, J., Lv, R., Qi, L., \& LaClair, T. J. (2019). Light-duty plug-in electric vehicles in China: an overview on the market and its comparisons to the United States. Renewable and Sustainable Energy Reviews, 112, 747-761. https://doi.org/10.1016/j.rser.2019.06.021.
Jenn, A., Azevedo, I. M. L., \& Michalek, J. J. (2016). Alternative fuel vehicle adoption increases fleet gasoline consumption and greenhouse gas emissions under United States corporate average fuel economy policy and greenhouse gas emissions standards. Environmental Science \& Technology, 50(5), 2165-2174. https://doi.org/10.1021/acs.est.5b02842.

Jenn, A., Azevedo, I. L., \& Michalek, J. J. (2019). Alternativefuel-vehicle policy interactions increase U.S. greenhouse gas emissions. Transportation Research Part A: Policy and Practice, 124, 396-407. https://doi.org/10.1016/j. tra.2019.04.003.

Publisher's note Springer Nature remains neutral with regard to jurisdictional claims in published maps and institutional affiliations. 